\title{
Synthesis of Metal and Metal Oxide Nanoparticles Using Plant Extract: a Review
}

\author{
Is Fatimah \\ Chemistry Department, Universitas Islam Indonesia \\ Gd. Zanzawi Soejoeti Lt.II, Kampus Terpadu Universitas Islam Indonesia, Jl. Kaliurang Km \\ 14, Sleman, Yogyakarta
}

\begin{abstract}
ABSTRAK
Nanoteknologi merupakan salah satu bidang teknologi yang dikembangkan saat ini dan banyak berkaitan dengan berbagai aplikasi. Dalam kaitannya dengan nanoteknologi tersebut, sintesis nanopartikel adalah teknologi yang dikembangkan dan seiring dengan perkembangan teknologi kimia yang berkaitan dengan konsep kimia hijau (green chemistry), penggunaan teknologi yang murah, keberlanjutan tinggi dan aman bagi lingkungan merupakan suatu kebutuhan. Terkait hal tersebut, sintesis nanopartikel dengan menggunakan ekstrak tanaman adalah teknik yang banyak dikembangkan. Dalam naskah ini disajikan kajian sintesis logam dan oksida logam penting dan berbagai aspeknya yang disajikan guna memberikan gambaran potensi sumber daya alam dalam mendukung sintesis nanopartikel dengan pendekatan green chemistry.
\end{abstract}

Kata-kata Kunci : Ekstrak tanaman, Green synthesis, Nanopartikel

\begin{abstract}
Nanotechnology is an emerging technology and it is related to various applications. Related to nanotechnology development, the use of green chemistry concept, low cost technology and sustainability is a must. Synthesis of nanoparticles using plant extract is a developing technique within the scheme. In this paper, study on metal/metal oxide synthesis and its aspects is presented for describing the potency of natural resources for nanoparticle synthesis within green chemistry approach.
\end{abstract}

Key Words: Plant extract, Green synthesis, Nanoparticles

\section{Pendahuluan}

Nanoteknologi adalah salah satu bidang teknologi yang berkembang pesat saat ini karena menawarkan beberapa solusi teknologi di berbagai bidang. Berdasarkan berbagai literatur sebenarnya nanoteknologi telah digunakan pada abadabad pertengahan dan bahkan abad sebelum masehi sebagai teknik pembuatan alat rumah tangga eksklusif atau senjata logam. Penelitian menunjukkan adanya pewarnaan yang berbeda dengan menggunakan nanopartikel tembaga pada berbagai gelas bermotif yang diproduksi pada (1200-1000 SM) dan dari penelitianpenelitian lain ditemukan adanya pelapisan emas dan perak pada beberapa senjata kerajaan romawi. Pondasi nanoteknologi 
ditengarai oleh penelitian sintesis nanopartikel emas ruby (Au NPs) oleh Michael Farady pada 1857 yang kemudian pada empat puluh tahun setelah itu dijadikan dasar sintesis logam dengan metode pembibitan (seed mediated method oleh Zsigmondy. Pada dasawarsa terakhir, perkembangan pesat nanoteknologi juga diprediksi akan merevolusi industri seperti fisika terapan, mekanik, kimia, teknik elektro dan biologis, desain mesin, robotika, dan obat-obatan sebagaimana disajikan melalui skema pada Gambar 1 dan Gambar 2.

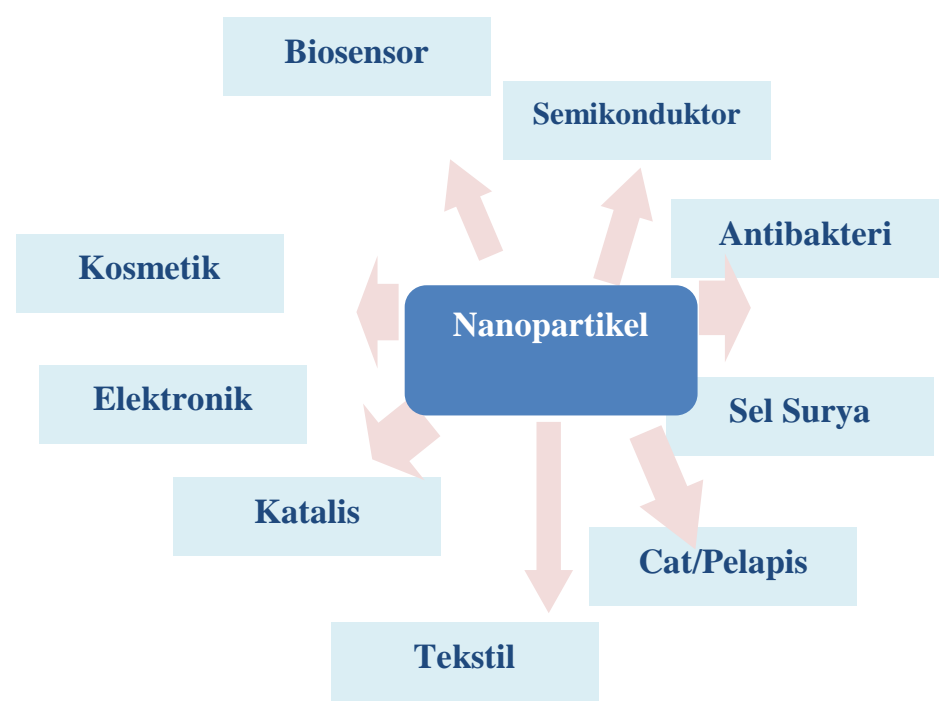

pencitraan medis misalnya, pengembangan nanopartikel telah menarik sejumlah penelitian fenomenal, terutama untuk aplikasi dalam pencitraan molekuler. Sebagai contoh, penggunaan nanopartikel emas untuk deteksi kanker sehingga memudahkan tatalaksana pencitraan dan pengendalian kanker cukup melalui injeksi nanopartikel. Ukuran nano $(<100 \mathrm{~nm})$ dari partikel-partikel ini memungkinkan konjugasi dengan banyak penanda molekuler, yang dapat berinteraksi pada tingkat molekuler dan seluler, sehingga dapat berikatan dengan molekul sebagai penanda target penyakit pada pencitraan molekuler.

$$
\text { Dalam bidang lingkungan, }
$$
beberapa nanopartikel semikonduktor menunjukkan peningkatan aktivitas fotokatalitik yang cukup besar pada aplikasinya sebagai fotokatalis, elektronik, sensor, pembawa obat (drug delivery), biosensors, pencitraan-bio (bio-imaging), agen antibakteri dan lain-lain.

Gambar 1. Berbagai aplikasi nanopartikel Beberapa aplikasi spesifik dari nanopartikel beberapa logam disajikan melalui skema pada Gambar 2. Dalam 


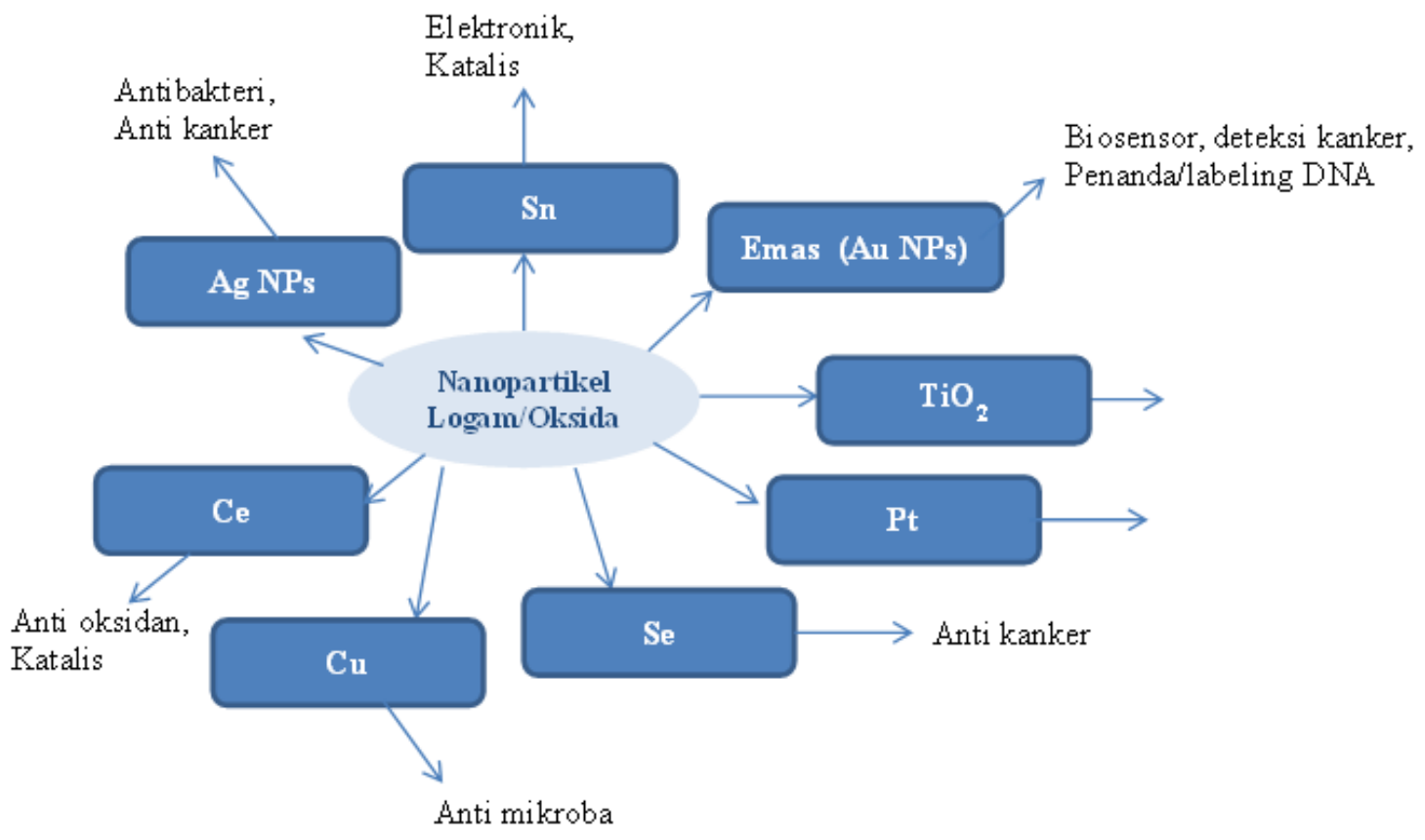

Gambar 2. Skema aplikasi nanopartikel logam/oksida logam

Seiring kebutuhan dan sintesis yang lebih besar tanpa perkembangan aplikasinya tersebut, menghasilkan produk sampingan

berbagai metode sintesis nanopartikel 3. Menggunakan bahan kimia yang aman: dikembangkan melalui konsep intensifikasi sintesis. Berkaitan hal tersebut, pendekatan kimia hijau (Green Chemistry) banyak metode sintesis diarahkan untuk mennghasilkan bahan kimia yang aman ke lingkungan.

diterapkan. Green chemistry sendiri merupakan konsep yang awalnya 4. Desain bahan kimia aman: mendesain bahan kimia yang tidak toksik.

dikemukakan oleh Paul Nastas, memuat 12 5. Pelarut aman: agen dan pelarut yang konsep dasar yang mengarah pada kimia berkelanjutan dan ramah lingkungan. Ke12 prinsip kimia hijau meliputi:

digunakan adalah yang benar-benar aman dan dibutuhkan.

1. Pencegahan polusi: prinsip ini adalah 6. Desain untuk efisiensi energi. lebih baik mencegah adanya limbah 7. Penggunaan bahan terbarukan daripada menangani limbah yang 8. Mereduksi derivatif ditimbulkan dari suatu proses.

9. Katalisis.

2. Atom Economy: dalam pengembangan metode sintesis diupayakan perolehan hasil

10. Desain untuk degradasi: produk/bahan kimia didesain untuk dapat didegradasi oleh lingkungan. 
11. Analisis real-time untuk pencegahan polusi.

12. Pencegahan kecelakaan dan bahan kimia aman.

Berkaitan dengan pendekatan kimia hijau, sintesis beberapa nanopartikel logam banyak dikembangkan ke arah penggunaan reagen kimia yang ramah lingkungan dan proses-proses yang efisien secara energi. Dalam skema tersebut penggunaan ekstrak tanaman sebagai reagen reduktor atau pencetak (template) nanopartikel banyak dipilih. Dalam makalah ini disampaikan kajian terhadap penggunaan ekstrak tanaman untuk sintesis beberapa nanopartikel logam atau dikenal sebagai biosintesis serta unjuk kerjanya pada berbagai aplikasi.

Pada umumnya reagen dari ekstrak tanaman berperanan menyumbangkan sifat reduksi dari kandungan metabolit di dalam tanaman baik bagian akar, batang, daun, buah maupun bunga tanaman. Kemampuan reduksi ekstrak tanaman disebabkan oleh adanya gugus-gugus fungsi aktif dari tanaman seperti alkenil $(\mathrm{C}=\mathrm{C})$, amida ( $\mathrm{C}=\mathrm{N})$, fenolik dan alcohol $(\mathrm{O}-\mathrm{H})$, amina ( $\mathrm{N}-\mathrm{H}$ ) dan karboksilat ( $\mathrm{COO}$ ) yang berasal dari metabolit sekunder tanaman sebagaimana dari beberapa senyawa teridentifikasi seperti katekin, gingerol dan flavonoidpada Gambar 3. Diselaraskan dengan penggunaan ekstrak tersebut, berbagai teknik dalam rangka intensifikasi antara lain penggunaan iradiasi gelombang mikro, penggunakan sonifikasi dan teknik reaksi lain yang menghasilkan pembentukan nanopartikel yang lebih cepat.<smiles>O=c1cc(-c2ccccc2)oc2ccccc12</smiles>

(a)<smiles>Oc1cc(O)c2c(c1)O[C@H](c1ccc(O)c(O)c1)[C@H](O)C2</smiles>

(b)<smiles>CCCCC[C@H](O)CC(=O)CCc1ccc(O)c(OC)c1</smiles>

(c)

Gambar 3. Struktur (a) Flavonoid (b) Katekin (c) Gingerol

\section{Sintesis nanopartikel Emas (Au NPs)}

Sintesis $\mathrm{Au}$ NPs adalah nanopartikel yang paling banyak dipublikasikan. Sintesis AuNPs 
kebanyakan diarahkan untuk aplikasi biomedis dan elektronik. Aplikasi biomedis dari AuNPs mengacu pada pengobatan Cina (Chinese medicine) dimana garam emas umumnya digunakan untuk perlakuan rheumatoid arthritis meskipun mekanisme kimiawinya belum bisa diketahui dengan pasti. Saat ini AuNPs dikembangkan umumnya pada aplikasi deteksi dan pembawa obat kanker dengan mekanisme sebagaimana disajikan pada Gambar 3. Pada aplikasi elektronik, AuNPs dikembangkan sebagai material perangkat ophto-electronic dan perangkat memori.

$\mathrm{Au}$ NPs disintesis melalui reaksi reduksi sederhana terhadap asam tetrakloro aurat $\left(\mathrm{HAuCl}_{4}\right)$ menggunakan natroum sitrat atau natrium borohidrat. Kombinasi reduksi dengan berbagai agen pencetak dapat menghasilkan AuNPs dengan berbagai bentuk antara lain nanoflower, nanorod atau nano Ulrich-like (Gambar 4).

Sintesis $\mathrm{Au}$ NPs dengan menggunakan ekstrak tanaman telah dilakukan oleh beberapa peneliti sebagaimana disajikan pada Tabel 1. Secara umum sintesis dilakukan dengan mencampurkan larutan asam tetrakloro aurat $\left(\mathrm{HAuCl}_{4}\right)$ dengan ekstrak tanaman dilanjutkan dengan pemeraman (aging) atau teknik percepatan pembentukan lain seperti penggunaan iradiasi gelombang mikro dan sonifikasi. Dari berbagai penelitian diperoleh bahwa parameter sintesis seperti konsentrasi, pH, waktu interaksi, temperature interaksi dll mempengaruhi morfologi dan ukuran AuNPs dalam sintesis. Sebagai contoh pada penelitian sintesis Au menggunakan ekstrak daun zaitun sebagai agen pereduksi, bentuk nanopartikel dipengaruhi konsentrasi ekstrak.

Pada konsentrasi ekstrak yang rendah $(0,5 \mathrm{~mL})$ diperoleh bentuk dominan segitiga dengan ukuran antara 50-100nm bersama dengan beberapa spesies berbentuk heksagonal dan pada kenaikan konsentrasi secara perlahan bentuk segitiga dan heksagonal hilang dan berubah menjadi sferik(Khalil et al., 2012). Identifikasi senyawa yang terkandung pada ekstrak tanaman menunjukkan senyawa potensial sebagai reduktor dalam daun zaitun antara lain oleuropin, apinen-7glikosida dan luteolin-7-glukosida dengan struktur sebagaimana disajikan pada Gambar 4. 
Tabel 1. Beberapa penelitian sintesis Au NPs dengan beberapa tanaman

\begin{tabular}{|c|c|c|c|}
\hline Tanaman & $\begin{array}{l}\text { Bentuk } \\
\text { nanopartikel }\end{array}$ & Ukuran & Referensi \\
\hline Calotropis procera & Sferik & $13-15 \mathrm{~nm}$ & (Das et al., 2012, 2011) \\
\hline Salvia officinalis & Segitiga & $36 \mathrm{~nm}$ & (Dzimitrowicz et al., 2016) \\
\hline Lippia citriodora & Pentagonal & 29 & (Kuppusamy et al., 2016) \\
\hline Punica granatum & Tidak seragam & 32 & (Dash and Bag, 2014) \\
\hline Magnolia kobus & $\begin{array}{l}\text { Segitiga, } \\
\text { Pentagonal } \\
\text { Heksagonal }\end{array}$ & $3-500$ & (Song et al., 2009) \\
\hline Diopyros kaki & $\begin{array}{l}\text { Segitiga, } \\
\text { Pentagonal } \\
\text { Heksagonal }\end{array}$ & $3-500$ & (Song et al., 2009) \\
\hline $\begin{array}{l}\text { Abelmoschus } \\
\text { esculentus }\end{array}$ & Sferik & $10-125 \mathrm{~nm}$ & (Jayaseelan et al., 2013) \\
\hline Menta & Segitiga & $10-100 \mathrm{~nm}$ & (Jafarizad et al., 2015) \\
\hline Pelargonium & Sferikal & $10-100 \mathrm{~nm}$ & (Jafarizad et al., 2015) \\
\hline Cassia auriculata & Segitiga dan Sferik & $15-25 \mathrm{~nm}$ & $\begin{array}{l}\text { (Dhayananthaprabhu et al., } \\
\text { 2013) }\end{array}$ \\
\hline Stevia rebaudiana & Sferikal & 2 and 50nm & (Sadeghi et al., 2015) \\
\hline Olive & $\begin{array}{l}\text { Morfologi } \\
\text { ditentukan oleh } \\
\text { konsentrasi ekstrak }\end{array}$ & & (Khalil et al., 2012) \\
\hline Aloe vera & Segitiga & $15.2 \mathrm{~nm}+/-4.2 \mathrm{~nm}$ & $\begin{array}{l}\text { (Muralikrishna et al., } \\
\text { 2014) }\end{array}$ \\
\hline $\begin{array}{l}\text { Citrus limon, } \\
\text { Citrus reticulata } \\
\text { and Citrus sinensis }\end{array}$ & Prisma dan sferikal & $15-80 \mathrm{~nm}$ & $\begin{array}{l}\text { (Sujitha and Kannan, } \\
\text { 2013) }\end{array}$ \\
\hline Mentha piperita & $\begin{array}{l}\text { Campuran segitiga, } \\
\text { heksagonal dan } \\
\text { sferik }\end{array}$ & $10-300 \mathrm{~nm}$ & (Dzimitrowicz et al., 2016) \\
\hline Centella asiatica & Tidak disebutkan & $9.3-10.9 \mathrm{~nm}$ & $\begin{array}{l}\text { (Das and Bibhuti Bhusan } \\
\text { Borthakur, 2010) }\end{array}$ \\
\hline $\begin{array}{l}\text { Cinnamomum } \\
\text { camphora }\end{array}$ & Tidak disebutkan & $40-100$ & (JL et al., 2017) \\
\hline
\end{tabular}


<smiles>C/C=C1\C(OC2OC(CO)[C@@H](O)[C@H](O)[C@H]2O)OC=C(C(=O)OC)C1CC(=O)OCCc1ccc(O)c(O)c1</smiles>

(a)<smiles>O=C1C=C(c2ccc(O)cc2)Cc2cc(O[C@@H]3O[C@H](CO)[C@@H](O)[C@H](O)[C@H]3O)cc(O)c21</smiles>

(b)<smiles>O=c1cc(-c2ccc(O)c(O)c2)oc2cc(OC3CCCCC3)cc(O)c12</smiles>

(c)

Gambar 4. Struktur (a) Oleuropin, (b) Apinen-7-glikosida dan (c) Luteolin-7-glukosida

Secara skematik pertumbuhan nanopartikel dalam sintesis menggunakan bioreduktor dapat diilustrasikan melalui Gambar 5. Identifikasi terbentuknya AuNPs melalui analisis spektrofotometri UV-Visible ditunjukkan dengan adanya panjang gelombang maksimum pada sekitar 520nm. Pergeseran panjang gelombang maksimum diperngaruhi oleh ukuran partikel sebagaimana disajikan melalui Gambar 6.

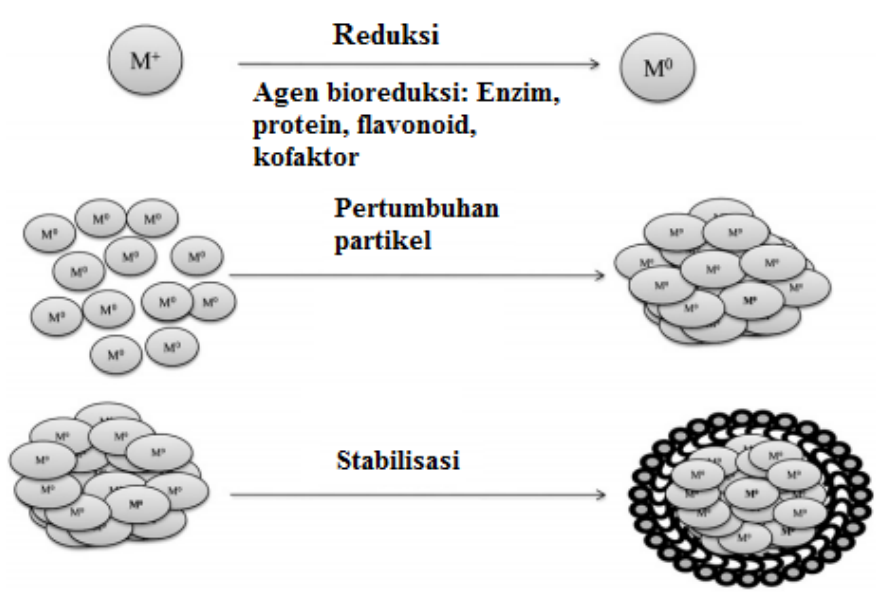

Gambar 5. Skema reduksi, pertumbuhan dan pembentukan nanopartikel (Kumar Mittal et al., 2013)
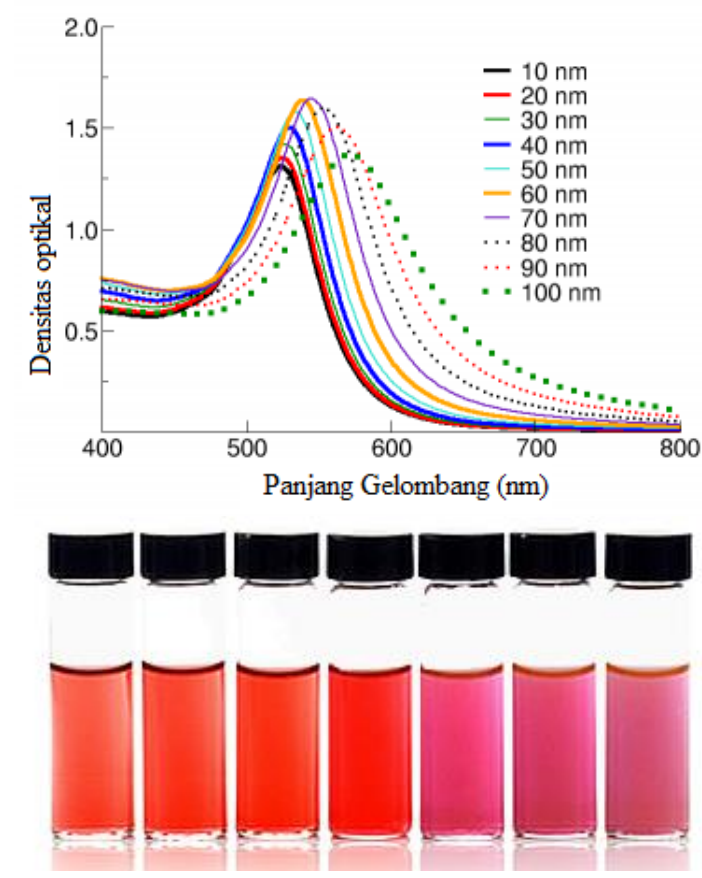

Gambar 6. Pengaruh ukuran nanopartikel terhadap densitas optik (Sumber: http://nanocomposix.com/page s/gold-nanoparticles-opticalproperties_ ) 


\section{Nanopartikel Perak (Ag NPs)}

Sintesis AgNPs pada umumnya dilakukan dalam kaitannya sebagai agen antibakteri, anti jamur antioksidasi dan beberapa aplikasi di bidang medis seperti deteksi virus, inhibisi HIV-1, pelapis (coating) peralatan dan tekstil medis/rumah sakit serta pelapis perban. Kim et al (2002) melaporkan bahwa Ag NPs memberikan aktivitas antibakteri pada 44 strain dari 6 spesies jamur dan strain ATCC dari Trichophyton mentagrophytes (T.entagrophytes) dan Candida albanicans (C. albanicans). Setidaknya aktivitas penghambatan $80 \%\left(\mathrm{IC}_{80}\right)$ dari $\mathrm{Ag}$ NPs adalah pada 1 hingga $7 \mu \mathrm{g} \mathrm{ml}^{-1}$. Berdasar kemampuan ini beberapa penelitian mengaplikasikan AgNPs sebagai pelapis plastik dan polimer. Sintesis AgNPs umumnya dilakukan dengan melarutkan $1 \mathrm{mM}$ larutan $\mathrm{AgNO}_{3}$ bersama ekstrak tanaman dalam proporsi 9:1 ( Gambar 7).

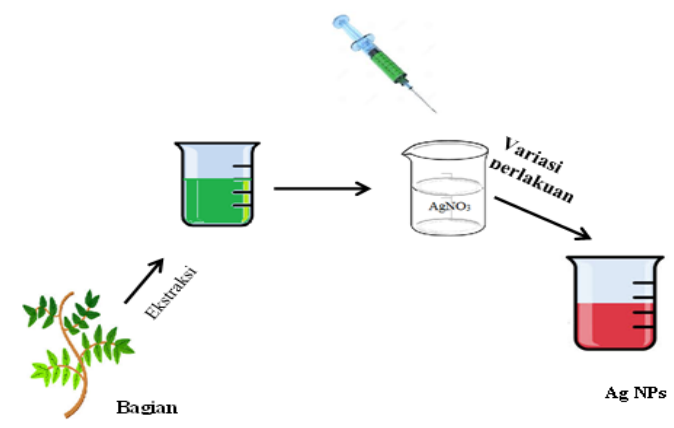

Gambar 7. Skema sintesis Ag NPs dengan ekstrak tanaman
Sama halnya dengan pembentukan nanopartikel pada emas, interaksi yang terjadi dalam sintesis adalah reduksi $\mathrm{Ag}^{+}$ oleh komponen tanaman sehingga pada umumnya nanopartikel yang terbentuk akan memberikan pola pelapisan ekstrak pada setiap partikel atau disebut sebagai capping sebagaimana ditunjukkan melalui hasil analisis menggunakan Tunnelling Electrone Microscope (TEM) pada Gambar 8.

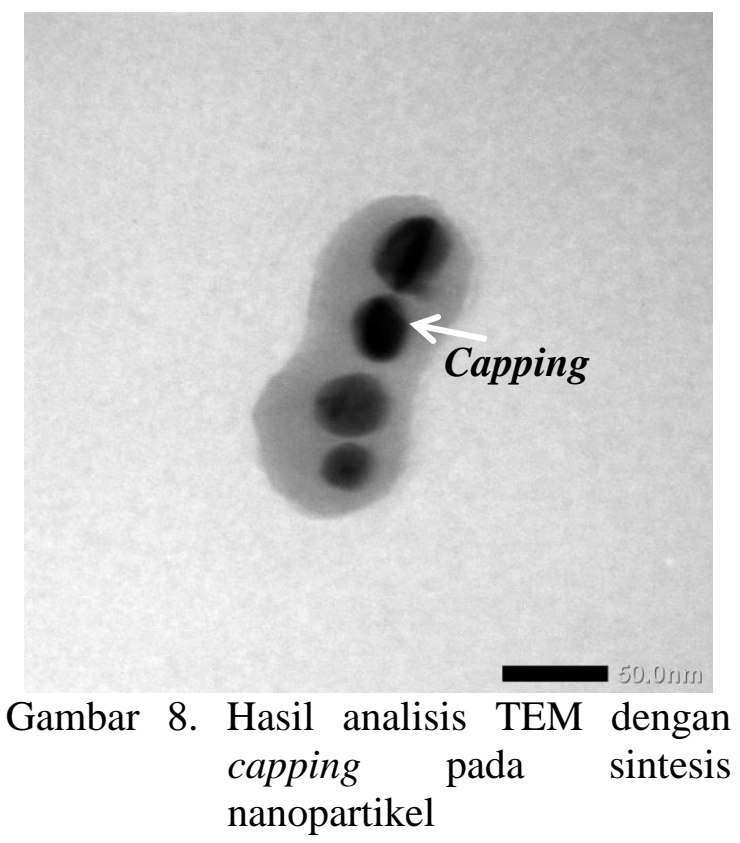

Dalam aplikasi sebagai antibakteri, pola nanopartikel ini memberikan keuntungan karena nanopartikel juga memberikan efek disebabkan ekstrak tersebut. Adanya pembentukan NPs ditandai dengan munculnya puncak pada panjang gelombang maksimum di sekitar 400-420nm. Berbagai penelitian 
menyajikan berbagai variasi perlakuan untuk mempercepat proses atau menghasilkan bentuk tertentu dari Ag NPs sebagaimana disajikan pada Tabel 2 . Sebagai contoh, perlakuan iradiasi gelombang mikro (MW) dapat digunakan untuk mempercepat pembentukan nanopartikel Ag dengan menggunakan ekstrak kulit pete (Parkia spesiossa hassk) memberikan spektra UV-Vis pada Gambar 9. Pada beberapa penelitian, pembentukan partikel $\mathrm{Ag}^{0}$ ditandai dengan analisis $x$-ray diffraction (XRD) dimana muncul puncakpuncak bersesuaian untuk $\mathrm{Ag}$ sesuai JCPDS No: seperti disajikan pada Gambar 10.

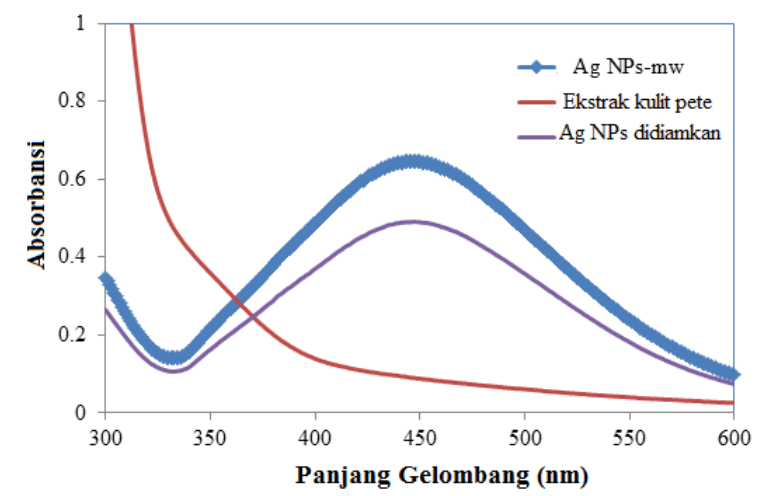

Gambar 9. Perbandingan spektra Ag NPs dengan metode didiamkan dan iradiasi gelombang mikro (Fatimah, 2016)

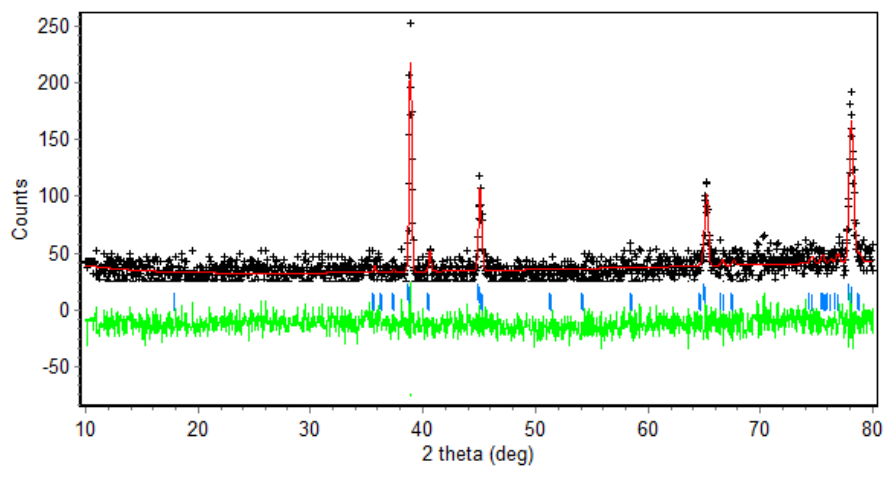

Gambar 10. Pola XRD Ag NPs

\section{Sintesis Nanopartikel ZnO}

Nanopartikel oksida seng/zinc oxide nanoparticles ( $\mathrm{ZnO}$ NPs) banyak digunakan sebagai material non-toksik, biosafe dan biokompatibel pada berbagai aplikasi di bidang kosmetika, antibakteri, cat dan polimer. Sintesis ramah lingkungan ZnO NPs menggunakan beberapa ekstrak tanaman disajikan pada Tabel 3. 
Tabel 2. Beberapa penelitian sintesis Ag NPs dengan beberapa tanaman

\begin{tabular}{|c|c|c|c|}
\hline Tanaman & Metode & Hasil & Referensi \\
\hline Sambucus nigra L. & $\begin{array}{l}\text { Sentrifugasi dan } \\
\text { radiasi foton }\end{array}$ & $\begin{array}{l}\text { Ukuran partikel 26nm } \\
\text { dan memiliki aktivitas } \\
\text { antioksidasi }\end{array}$ & $\begin{array}{l}\text { (Moldovan et al., } \\
\text { 2016) }\end{array}$ \\
\hline $\begin{array}{l}\text { Myristica fragrans } \\
\text { (nutmeg) }\end{array}$ & Sentrifugasi & Ukuran antara 7-20nm & $\begin{array}{l}\text { (Sharma et al., } \\
\text { 2014) }\end{array}$ \\
\hline $\begin{array}{l}\text { Malus domestica } \\
\text { (red }\end{array}$ & - & Ukuran partikel $145 \mathrm{~nm}$ & $\begin{array}{l}\text { (Umoren et al., } \\
\text { 2014) }\end{array}$ \\
\hline (Citrus limon & - & $\begin{array}{l}\text { Ukuran partikel 8,27- } \\
\text { 14,48nm dan memiliki } \\
\text { aktivitas (Vankar and } \\
\text { Shukla, 2012)antibakteri } \\
\text { dan anti jamur }\end{array}$ & $\begin{array}{l}\text { (Vankar and } \\
\text { Shukla, 2012) }\end{array}$ \\
\hline Malus domestica) & $\begin{array}{l}\text { Radiasi gelombang } \\
\text { mikro }\end{array}$ & $\begin{array}{l}\text { Ukuran partikel } 10-45 \mathrm{~nm} \\
\text { dan memiliki aktivitas } \\
\text { antibakteri }\end{array}$ & $\begin{array}{l}\text { (Vijayashree et al., } \\
\text { 2014) }\end{array}$ \\
\hline $\begin{array}{l}\text { Parkia spessiosa } \\
\text { Hask }\end{array}$ & $\begin{array}{l}\text { Radiasi gelombang } \\
\text { mikro }\end{array}$ & Ukuran partikel & \\
\hline Lantana camara $L$ & Sonokasi & $\begin{array}{l}\text { Ukuran partikel } 33.8 \mathrm{~nm} \\
\text { dan menunjukkan } \\
\text { aktivitas antioksidasi }\end{array}$ & $\begin{array}{l}\text { (VP and } \\
\text { Muthukumar K., } \\
\text { 2016) }\end{array}$ \\
\hline Pisonia grandis & Sonikasi & Ukuran partikel < 150nm & $\begin{array}{l}\text { (Firdhouse et al., } \\
\text { 2012) }\end{array}$ \\
\hline Ananas comosus & Sonikasi & Ukuran partikel $12 \mathrm{~nm}$ & $\begin{array}{l}\text { (Ahmad and } \\
\text { Sharma, 2012) }\end{array}$ \\
\hline $\begin{array}{l}\text { Bergenia ciliata } \\
\text { extract. }\end{array}$ & - & $\begin{array}{l}\text { Ukuran partikel } 35 \mathrm{~nm} \\
\text { dengan bentuk sferik }\end{array}$ & $(\mathrm{Zia}, 2016)$ \\
\hline $\begin{array}{l}\text { Abutilon indicum } \\
\text { (L.) }\end{array}$ & - & $\begin{array}{l}\text { Ukuran partikel } 106 \mathrm{~nm} \\
\text { dan memiliki aktivitas } \\
\text { anti bakteri terhadap } \\
\text { Klebsiella pneumoniae, } \\
\text { Proteus vul- garis, } \\
\text { Salmonella typhi, and } \\
\text { Bacillus subtilis }\end{array}$ & $\begin{array}{l}\text { (Alagersamy, } \\
\text { 2016) }\end{array}$ \\
\hline $\begin{array}{l}\text { Clitoria ternatea } \\
\text { Dan } \\
\text { Solanum nigrum }\end{array}$ & - & $\begin{array}{l}\text { Nanopartikel memiliki } \\
\text { aktivitas anti pathogen } \\
\text { Nosocomial }\end{array}$ & $\begin{array}{l}\text { (Krithiga et al., } \\
\text { 2015) }\end{array}$ \\
\hline Azadirachta indica & & $\begin{array}{l}\text { Pembentukan } \\
\text { nanopartikel ditunjukkan } \\
\text { dengan spectra pada } 280 \\
\text { dan } 561 \mathrm{~nm} \text { dan eksitasi } \\
\text { pada } 280 \mathrm{~nm} \text {. }\end{array}$ & $\begin{array}{l}\text { (Ahmed et al., } \\
\text { 2015) }\end{array}$ \\
\hline
\end{tabular}




\begin{tabular}{|c|c|c|c|}
\hline Tanaman & Metode & Hasil & Referensi \\
\hline Mangifera indica & & $\begin{array}{l}\text { Ukuran partikel } 30.25 \pm \\
5.26 \mathrm{~nm} \text { dan aktivitas } \\
\text { antibakteri gram positif } \\
\text { dan gram negative } \\
\text { dengan konsentrasi } \\
\text { minimum penghambatan } \\
(\mathrm{MIC})=125 \mu \mathrm{g} / \mathrm{mL} \\
\text { hingga } 1000 \mu \mathrm{g} / \mathrm{mL} \text {. }\end{array}$ & (Ali et al., 2016) \\
\hline $\begin{array}{l}\text { Cinnamon } \\
\text { zeylanicum }\end{array}$ & & $\begin{array}{l}\text { Nanopartikel memiliki } \\
\text { nilai } \\
\text { EC }_{50} \text { terhadap Escherichi } \\
\text { a coli } \mathrm{BL}-21 \text { strain } \\
\text { sebesar } 11 \pm 1.72 \mathrm{mg} / \mathrm{L}\end{array}$ & \\
\hline
\end{tabular}

Pada kebanyakan penelitian digunakan prekursor zink asetat atau seng nitrat dengan konsentrasi 0,01M-0,1M. Proses sintesis dilakukan dengan mencampurkan larutan precursor dengan ekstrak tanaman dan larutan dikondisikan pada $\mathrm{pH}$ basa (antara 8-13). Keberadaan $\mathrm{ZnO}$ ditunjukkan dengan adanya puncak pada analisis UV pada sekitar 290-350nm, namun pada kenyataannya beberapa kandungan alkaloid dan kandungan flavonoid dari ekstrak juga memberikan puncak pada wilayah 250-300nm.

Oleh karena hal ini maka penegasan adanya $\mathrm{ZnO}$ diperlukan dengan menggunakan beberapa analisis lainnya seperti menggunakan XRD dan TEM. Keberadaan $\mathrm{ZnO}$ dengan analisis XRD mengacu pada spectra standard JCPDS No. 361451 dimana puncak-puncak $\mathrm{ZnO}$ akan muncul pada nilai $2 \theta=31.77^{\circ}, 34.40^{\circ}$, $36.22^{\circ}, 47.61^{\circ}, 56.58^{\circ}, 62.85^{\circ}, 66.41^{\circ}$, $67.93^{\circ}, 69.08^{\circ}, 72.54^{\circ}$ dan $76.85^{\circ}$ bersesuaian dengan bidang kisi (100), (002), (101), (102), (110), (103), (200), (112), (201), (004) dan (202). Hasil penelitian menunjukkan bahwa reaksi reduksi dipengaruhi oleh kuantitas ekstrak yang ditambahkan di dalam sintesis seperti dilaporkan pada penggunaan daun rosella (Hibiscus subdariff) dalam sintesis $\mathrm{ZnO}$ dengan grafik pada Gambar 11 (Bala et al., 2014).

Tabel 3. Beberapa penelitian sintesis $\mathrm{ZnO}$ NPs dengan beberapa tanaman

\begin{tabular}{|c|c|c|}
\hline Tanaman & Hasil & Referensi \\
\hline $\begin{array}{l}\text { Nyctanthes } \\
\text { arbor-tristis }\end{array}$ & $\begin{array}{l}\text { Bentuk sferik } \\
\text { dengan ukuran } \\
\text { partikel } 12-32 \\
\text { nm }\end{array}$ & $\begin{array}{l}\text { (Jamdagni et } \\
\text { al., 2016) }\end{array}$ \\
\hline $\begin{array}{l}\text { Ocimum } \\
\text { Tenuiflorum }\end{array}$ & $\begin{array}{l}\text { Bentuk } \\
\text { heksagonal } \\
\text { dengan ukuran } \\
11-25 \mathrm{~nm}\end{array}$ & $\begin{array}{l}\text { (Raut et al., } \\
2015 \text { ) }\end{array}$ \\
\hline
\end{tabular}




\begin{tabular}{|c|c|c|c|c|c|}
\hline Tanaman & Hasil & Referensi & \multicolumn{3}{|c|}{ pada kadar } \\
\hline \multirow{4}{*}{$\begin{array}{l}\text { Hibiscus } \\
\text { subdariffa }\end{array}$} & Bentuk & (Bala et al., & & getah yang & \\
\hline & $\begin{array}{l}\text { campuran } \\
\text { antara sferik } \\
\text { dan bentuk }\end{array}$ & 2014) & & $\begin{array}{l}\text { digunakan } \\
\text { dalam } \\
\text { bioreduksi }\end{array}$ & \\
\hline & gendang, & & Sesbania & Ukuran & ( $\mathrm{R}$ and \\
\hline & ukuran antara & & Grandiflora & $\begin{array}{l}\text { partikel antara } \\
43-46 \mathrm{~nm} \text { dan }\end{array}$ & Rajalaxshmi, \\
\hline \multirow{10}{*}{$\begin{array}{l}\text { Phyllanthus } \\
\text { embilica }\end{array}$} & Bentuk sferik & (Joel et al., & & menunjukkan & \\
\hline & dengan ukuran & 2016) & & aktivitas & \\
\hline & $\begin{array}{l}25-35 \mathrm{~nm} \\
\text { dan memiliki }\end{array}$ & & & $\begin{array}{l}\text { fotokatalitik, } \\
\text { aktivitas }\end{array}$ & \\
\hline & aktivitas & & & fotokatalitik & \\
\hline & antibakteri & & & dikuatkan & \\
\hline & terhadap & & & dengan & \\
\hline & Salmonella & & & dopping $\mathrm{Ce}$ & \\
\hline & typhi & & Leucas & Pembentukan & (Manokari \\
\hline & Klebsiella dan & & aspera & $\mathrm{ZnO}$ NPs & and \\
\hline & $\begin{array}{l}\text { Klebsiella } \\
\text { phnemoniea }\end{array}$ & & (Willd.) L & $\begin{array}{l}\text { ditandai } \\
\text { dengan adanya }\end{array}$ & $\begin{array}{l}\text { Shekhawat, } \\
\text { 2016c) }\end{array}$ \\
\hline Ixora & Ukuran & (Yedurkar et & & puncak pada & \\
\hline Coccinea & $\begin{array}{l}\text { partikel } 145.1 \\
\text { nm }\end{array}$ & al., 2016) & & $\begin{array}{l}302 \text { dan } 305 \\
\text { nm dari }\end{array}$ & \\
\hline Passiflora & Bioreduksi & (Manokari & & analisis & \\
\hline edulis Sims. & ditunjukkan & and & & spektrofotome & \\
\hline f. flavicarpa & dengan adanya & Shekhawat, & & ter UV-Vis & \\
\hline
\end{tabular}

Deg. M. $\quad$ puncak UV 2016a)

pada $332 \mathrm{~nm}$ dari ekstrak daun, $296 \mathrm{~nm}$ dari ekstrak batang dan $326 \mathrm{~nm}$ dari ekstrak bunga

Couroupita Pembentukan guianensis nanopartikel Aubl. ditunjukkan (Manokari and dengan spectra 2016b) pada $290 \mathrm{~nm}-$ hingga $302 \mathrm{~nm}$

Getah Nilai energi (Sakthivel et Azadirachta celah pita al., 2016) indica (band gap energy) $\mathrm{ZnO}$ NPs bervariasi

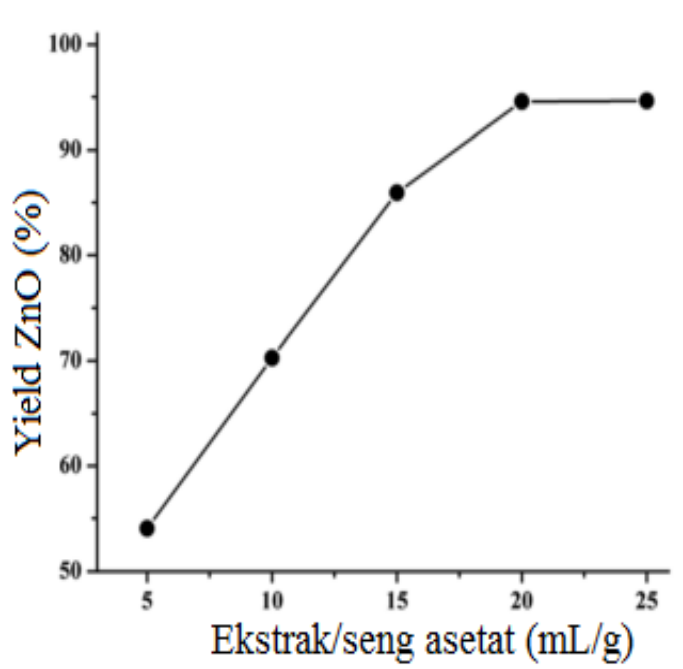

Gambar 11. Pengaruh kadar ekstrak tanaman terhadap yield $\mathrm{ZnO}$ tergantung 


\section{Sintesis Nanopartikel Oksida Besi}

Oksida besi yang tersedia dalam beberapa fase di alam. Oksida besi memiliki potensi yang cukup besar pada beberapa aplikasi industry dan lingkungan antara lain pada teknologi sensor, katalisis dan fotokatalisis. Oksida besi relatif inert, tidak beracun, dan hadir dalam organisme hidup.

Dari beberapa oksida besi nanopartikel yang dilaporkan, $\alpha-\mathrm{Fe}_{2} \mathrm{O}_{3}$ atau disebut sebagai hematit adalah yang paling banyak dilaporkan. Hal ini karena kemudahan pembentukandan stabilitas fase dibandingkan yang lain. Dalam sintesis kimiawi konvensional, nanopartikel oksida besi (Fe NPs) disintesis dari campuran antara besi nitrat sebagai precursor dengan natrium borohidrat atau hidrazin hidrat yang berfungsi sebagai reduktor.

Pada perkembangan selanjutnya beberapa penelitia melaporkan penggunaan bahan kimia yang lebih aman seperti asam askorbat, glukosa dan sodium alginate (Saif et al., 2016). Tabel 4 menyajikan berbagai ekstrak tanaman dan hasil sintesis yang dilaporkan dari berbagai penelitian.

\section{Sintesis Nanopartikel $\mathrm{TiO}_{2}$}

Nanopartikel titanium dioksida

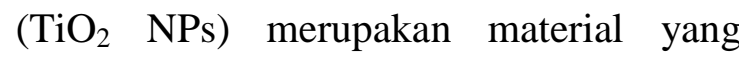

menarik dengan sifat optik, antimikrobial dan stabilitas kimiawi yang bagus dan digunakan dalam berbagai aplikasi seperti pada industri pugmen, filler, katalis dan fotokatalis. Dalam menggunakan ekstrak tanaman beberapa prekursor dilaporkan antara lain $\quad \mathrm{TiO}(\mathrm{OH})_{2}$, titanium tetraisopropoksida dan titanium dioksida.

Tabel 5 menyajikan beberapa penelitian sintesis $\mathrm{TiO}_{2}$ NPs menggunakan beberapa ekstrak tanaman. Salah satu yang menarik dari sintesis menggunakan ekstrak Calontrophis gigantea yakni aktivitas anti larva Haemaphysalis bispinosa dengan nilai $\mathrm{LC} 50=35.22$ dan $9.15 \mathrm{mg} / \mathrm{L}$.

Identifikasi $\mathrm{TiO}_{2}$ yang terbentuk dilakukan menggunakan XRD dengan puncak-puncak spesifik untuk anatase yakni pada $2 \theta=25.3^{\circ}, 37.8^{\circ}, 47.9,54.5^{\circ}$, $62.8^{\circ}, 69.5^{\circ}$ dan $75.1^{\circ}$ bersesuaian dengan bidang kisi 101, 004, 200, 105, 204, 116 dan 215 ((JCPDS No.21-1272).

Dari serangkaian penelitianpenelitian sintesis nanopartikel berbagai logam dan oksida logam dapat ditarik benang merah yakni adanya pemanfaatan bahan alam yang lebih aman dan dalam beberapa hal memberikan sumbangan kepada aktivitas biologis nanopartikel. 
Tabel 4. Beberapa penelitian sintesis nanopartikel oksida besi dengan beberapa tanaman

\begin{tabular}{|c|c|c|}
\hline Tanaman & Hasil & Referensi \\
\hline Citrus medica & $\begin{array}{l}\mathrm{Fe}_{2} \mathrm{O}_{3} \mathrm{NPs} \text { memiliki } \\
\text { aktivitas antibakteri } \\
\text { terhadao E.coli }\end{array}$ & (Al-kalifawi, 2015) \\
\hline Piper betle & $\begin{array}{l}\mathrm{Fe}_{2} \mathrm{O}_{3} \text { NPs memiliki } \\
\text { ukuran partikel rerata } \\
\text { sebesar } 60 \mathrm{~nm} \text { dan } \\
\text { menunjukkan aktivitas } \\
\text { fotokatalitik }\end{array}$ & (Leonard, 2015) \\
\hline $\begin{array}{l}\text { The hijau, the Oolong, The } \\
\text { hitam }\end{array}$ & $\begin{array}{l}\text { Fe NPs menunjukkan } \\
\text { aktivitas katalitik pada } \\
\text { proses reduksi } \\
\text { klorobenzena secara } \\
\text { Fenton }\end{array}$ & (Kuang et al., 2013) \\
\hline Eucalyptus Globulus & $\begin{array}{l}\text { Diperoleh nanopartikel } \\
\text { campuran antara } \propto-\mathrm{Fe}_{2} \mathrm{O}_{3} \\
\text { dan } \beta-\mathrm{Fe}_{2} \mathrm{O}_{3}\end{array}$ & (Balamurughan et al., 2014) \\
\hline Tridax procumbens & $\begin{array}{l}\text { Nanopartikel memiliki } \\
\text { aktivitas anti bakteri } \\
\text { signifikan pada }\end{array}$ & (Senthil and Ramesh, 2012) \\
\hline Carica papaya & $\begin{array}{l}\text { Pseudomonas aeruginosa } \\
\propto-\mathrm{Fe}_{2} \mathrm{O}_{3} \text { dengan ukuran } \\
\text { rerata partikel 33nm }\end{array}$ & (Latha and Gowri, 2014) \\
\hline Acanthophyllum Bracteatum & Ukuran partikel 30-46 nm & (Omidvari et al., n.d.) \\
\hline
\end{tabular}

Tabel 5. Beberapa penelitian biosintesis $\mathrm{TiO}_{2}$ NPs

\begin{tabular}{|c|c|c|c|}
\hline Tanaman & Prekursor & Hasil & Referensi \\
\hline $\begin{array}{l}\text { Euphorbia } \\
\text { prostata }\end{array}$ & $\mathrm{TiO}(\mathrm{OH})_{2}$ & $\begin{array}{l}\text { Ukuran nanopartikel 12- } \\
83 \mathrm{~nm}\end{array}$ & (Zahir et al., 2014) \\
\hline $\begin{array}{l}\text { Calotropis } \\
\text { gigantea against }\end{array}$ & $\mathrm{TiO}(\mathrm{OH})_{2}$ & Ukuran partikel 10nm & (Marimuthu et al., 2013) \\
\hline Vigna radiata & $\mathrm{TiO} 2$ & $\begin{array}{l}\text { Nanopartikel yang } \\
\text { diperoleh efektif pada } \\
\text { bakteri gram positif dan } \\
\text { gram negatif, aktivitas } \\
\text { antioksidasi dan aktivitas } \\
\text { sitotoksisitas terhadap } \\
\text { osteosarcoma cell lines }\end{array}$ & (Chatterjee et al., 2016) \\
\hline $\begin{array}{l}\text { Nyctanthes } \\
\text { arbor-tristis }\end{array}$ & & $\begin{array}{l}\text { Nanopartikel yang } \\
\text { terbentuk berbentuk } \\
\text { kubik dan sferik dengan } \\
\text { ukuran } 100-150 \mathrm{~nm}\end{array}$ & $\begin{array}{l}\text { (M. and SSundraraja, } \\
\text { 2011) }\end{array}$ \\
\hline Aloe vera & Titanium dioksida & $\begin{array}{l}\text { Nanopartikel memiliki } \\
\text { energi celah pita } 3,19 \mathrm{eV}\end{array}$ & (Khadar et al., 2016) \\
\hline
\end{tabular}




\begin{tabular}{|c|c|c|c|}
\hline Tanaman & Prekursor & Hasil & Referensi \\
\hline Nyctanthes arbor & $\begin{array}{l}\text { Titanium } \\
\text { tetraisopropoksida }\end{array}$ & $\begin{array}{l}\text { Ukuran partikel } 100 \text { to } \\
150 \mathrm{~nm}\end{array}$ & \\
\hline Eclipta prostrata & $\mathrm{TiO}(\mathrm{OH})_{2}$ & $\begin{array}{l}\text { Ukuran partikel 36-68 } \\
\text { nm }\end{array}$ & (Rajakumar et al., 2012) \\
\hline Jatropha curcas & $\mathrm{TiO}(\mathrm{OH})_{2}$ & $\begin{array}{l}\text { Ukuran partikel 25- } 100 \\
\mathrm{~nm}\end{array}$ & (Hudlikar et al., 2012) \\
\hline $\begin{array}{l}\text { Solanum } \\
\text { trilobatum }\end{array}$ & $\mathrm{TiO}(\mathrm{OH})_{2}$ & $\begin{array}{l}\text { Ukuran partikel rerata } \\
70 \mathrm{~nm}\end{array}$ & (Rajakumar et al., 2014) \\
\hline Eclipta prostrate & $\mathrm{TiO}(\mathrm{OH})_{2}$ & Ukuran partikel 45,5 nm & $\begin{array}{l}\text { (Krishnasamy et al., } \\
\text { 2015) }\end{array}$ \\
\hline $\begin{array}{l}\text { Azadirachta } \\
\text { indica }\end{array}$ & $\mathrm{TiO} 2$ & $\begin{array}{l}\text { Partikel berbentuk sferik } \\
\text { degan ukuran } 15-42 \mathrm{~nm}\end{array}$ & $\begin{array}{l}\text { (Krishnasamy et al., } \\
\text { 2015) }\end{array}$ \\
\hline
\end{tabular}

Nanopartikel Platinum dan Paladium

Biosintesis platinum dan palladium juga banyak dilaporkan meskipun tidak dalam jumlah yang sama dengan sintesis nanopartikel Ag atau Au. Faktor utamanya adalah karena kedua logam memiliki harga yag cukup mahal. Meski demikian kedua logam bersifat eksklusif terutama pada penanganan dan deteksi kanker. Dalam beberapa penelitian sintesis $\mathrm{Pt}$ dan $\mathrm{Pd}$ dengan menggunakan ekstrak tanaman mengambil precursor asam heksa kloro platinat $\left(\mathrm{H}_{2} \mathrm{PtCl}_{6}\right)$ dan palladium asetat $\left(\mathrm{Pd}\left(\mathrm{CH}_{3} \mathrm{COO}\right)_{2}\right)$. Beberapa paper penting dalam sintesis $\mathrm{Pt}$ menggunakan ekstrak tanaman antara lain penggunaan ekstrak Annacardium occidentale, Ocimum sanctum, Ocimum santum, dan Azadirachta indica (A et al., 2016; C et al., 2012; Shenya et al., 2013).

Dilaporkan bahwa dengan meggunakan ekstrak Annacardium occidentale diperoleh nanopartikel berbentuk batang yang ukurannya tergantung pada konsentrasi ekstrak yang ditambahkan. Adanya kandungan asam askorbat dan terpenoid ditengarai merupakan factor penentu reduksi $\mathrm{Pt}$ menggunakan Ocimum sanctum.

Sintesis palladium dilaporkan menggunakan ekstrak Catharanthus roseus, Hippophae rhamnoides dan Sargassum bovinum. Adanya senyawa fenolik pada ekstrak tanaman dapat mereduksi palladium asetat dengan reaksi sebagai berikut:.

$\mathrm{Pd}\left(\mathrm{CH}_{3} \mathrm{COO}\right)_{2}+$ Ekstrak $\rightarrow \quad \mathrm{Pd}$ $+2 \mathrm{CH}_{3} \mathrm{COOH}$

Pembentukan nanopartikel ditandai dengan adanya puncak UV-Vis pada 360-400nm.

\section{Kesimpulan}

Berbagai ekstrak tanaman dilaporkan berperranan dalam sintesis 
nanopartikel logam/oksida logam. Ukuan, bentuk dan aktivitas nanopartikel sangat tergantung pada jenis, konsentrasi dan kondisi sintesis nanopartikel dan selain itu peranan dan aktivitas nanopartikel bervariasi pada berbagai bidang. Mengingat potensi sumber daya alam Indonesia khususnya pada biodiversitas sangat besar, berbagai laporan ini membuka peluang bagi upaya green synthesis menggunakan ekstrak tanaman yang fungsional sehingga menghasilkan material dengan fungsi yang karakteristik.

\section{Ucapan Terimakasih}

Penulis mengucapkan terimakasih kepada Program Studi Kimia yang telah memberikan dukungan dana penelitian dalam skema Pengembangan Research Excellencies Program Studi 2016.

\section{Pustaka}

A, Thirumurugan., P, Aswitha., C, Kiruthika., S, Nagarajan., Cristy, N., 2016, Green synthesis of platinum nanoparticles using Azadirachta indica - An eco-friendly approach, Mater. Lett., 170: 175-178.

Ahmad, N., Sharma, S., 2012, Green Synthesis of Silver Nanoparticles Using Extracts of Ananas comosus, Green and Sustainable Chemistry, 2, 141-147. doi:10.4236/gsc.2012.24020

Ahmed, S., Ahmad, M., Swami, B.L.,
2015, ScienceDirect Green synthesis of silver nanoparticles using Azadirachta indica aqueous leaf extract, Journal of Radiation Research and Applied Sciences, 9, 17. doi:10.1016/j.jrras.2015.06.006

Al-kalifawi, E.J., 2015, Green synthesis Of Magnetite Iron Oxide Nanoparticles by Using Al-Abbas â€ $€^{\mathrm{TM}} \mathrm{s}$ ( A . S .) Hund Fruit ( Citrus medica) var . Sarcodactylis Swingle Extract and Used in Al- $\hat{a} €^{\mathrm{TM}}$ alqami River Water Treatment, J. Nat.Si. Res., 5, 125135.

Alagersamy, A., 2016, Anti-bacterial activities of silver nanoparticles synthesized from plant leaf extract of Abutilon indicum ( L .) Sweet, J.Nanostruct.Chem, 4: 106-110. 1110doi:10.1007/s40097-010106-1

Ali, Z.A., Yahya, R., Sekaran, S.D., Puteh, R., 2016, Green Synthesis of Silver Nanoparticles Using Apple Extract and Its Antibacterial Properties, J.Mater.Environ.Sci., 3, 907-916.

Bala, N., Saha, S., Chakraborty, M., Maiti, M., Das, S., Basu, R., Nandy, P., 2014, RSC Advances Green synthesis of zinc oxide nanoparticles using Hibiscus subdari ff a leaf extract: e ff ect of. RSC Advances, 5, 4993-5003. doi:10.1039/C4RA12784F

Balamurughan, M.G., Mohanraj, S., Kodhaiyolii, S., Pugalenthi, V., 2014, National Conference on Green Engineering and Technologies for Sustainable Future-2014 Ocimum sanctum leaf extract mediated green synthesis of iron oxide nanoparticles : spectroscopic and microscopic studies National Conference on Green Engineering and Tec. Journal of Chemical and Pharmaceutical Sciences, 201-204.

C, S., A, S., P, D., S, M., S, R., G, S., N., P., 2012, Rapid biological synthesis 
of platinum nanoparticles using Ocimum sanctum for water electrolysis applications, Bioprocess Biosyst Eng. 35, 827-833.

Chatterjee, A., Nishanthini, D., Sandhiya, N., Abraham, J., 2016. Biosynthesis of titanium dioxide nanoparticles using vigna radiata, Asian J.Pharm.Clinical Res., 9, 4-7.

Das, R.K., Bibhuti Bhusan Borthakur, U.B., 2010, Green synthesis of gold nanoparticles using ethanolic leaf extract of Centella asiatica, Materials Letters, 64, 1445-1447.

Das, R.K., Punuri Jayasekhar Babu, N.G., Sharma, P., Bora, U., 2012, Microwave-Mediated Rapid Synthesis of Gold Nanoparticles Using Calotropis procera Latex and Study of Optical Properties, ISRN Nanomaterials, Article ID 650759.

Das, R.K., Sharma, P., Nahar, P., Bora, U., 2011, Synthesis of gold nanoparticles using aqueous extract of Calotropis procera latex, Materials Letters, 65, 610-613.

Dash, S.S., Bag, B.G., 2014, Synthesis of gold nanoparticles using renewable Punica granatum juice and study of its catalytic activity, Applied Nanoscience, $\quad \mathbf{4}, \quad 55-59$. doi:10.1007/s 13204-012-0179-4

Dhayananthaprabhu, J., Lakshmi Narayanan, R., Thiyagarajan, K., 2013, Facile Synthesis of Gold (Au) Nanoparticles Using Cassia auriculata Flower Extract, Advanced Materials Research, 678, 12-16. doi:10.4028/www.scientific.net/AMR .678 .12

Dzimitrowicz, A., Jamróz, P., diCenzo, G.C., Sergiel, I., Kozlecki, T., Pohl, P., 2016, Preparation and characterization of gold nanoparticles prepared with aqueous extracts of Lamiaceae plants and the effect of follow-up treatment with atmoSferik pressure glow microdischarge, Arabian Journal of Chemistry, article in

doi:10.1016/j.arabjc.2016.04.004

Fatimah, I., 2016, Green synthesis of silver nanoparticles using extract of Parkia speciosa Hassk pods assisted by microwave irradiation, Journal of Advanced Research, 7, 961-969. doi:10.1016/j.jare.2016.10.002

Firdhouse, M.J., Lalitha, P., Sripathi, S.K., 2012, Novel synthesis of silver nanoparticles using leaf ethanol extract of Pisonia grandis ( $\mathrm{R}$. Br ), Der Pharma Chemica, 4, 2320-2326.

Hudlikar, M., Joglekar, S., Dhaygude, M., Kodam, K., 2012, Green synthesis of TiO 2 nanoparticles by using aqueous extract of Jatropha curcas L . latex, Materials Letters, 75, 196-199. doi:10.1016/j.matlet.2012.02.018

Jafarizad, A., Safaee, K., Gharibian, S., Omidi, Y., Ekinci, D., 2015, Biosynthesis and In-vitro Study of Gold Nanoparticles Using Mentha and Pelargonium Extracts, Procedia Materials Science, 11, 224-230. doi:10.1016/j.mspro.2015.11.113

Jamdagni, P., Khatri, P., Rana, J.S., 2016, Green synthesis of zinc oxide nanoparticles using flower extract of Nyctanthes arbor-tristis and their antifungal activity, Journal of King Saud University - Science, doi:10.1016/j.jksus.2016.10.002

Jayaseelan, C., Ramkumar, R., Rahuman, A.A., Perumal, P., 2013, Green synthesis of gold nanoparticles using seed aqueous extract of Abelmoschus esculentus and its antifungal activity, Industrial Crops \& Products, 45, 423-429.

doi:10.1016/j.indcrop.2012.12.019

JL, H., QB, L., DH, S., YH, L., YB, S., Yang X, et al., 2017,. Biosynthesis of 
silver and gold nanoparticles by novel sundried Cinnamomum camphora leaf, Nanotechnology 18 (10), 1-10.

Joel, C., Badhusha, M.S.M., John, S., 2016, Green synthesis of $\mathrm{ZnO}$ Nanoparticles using Phyllanthus embilica Stem extract and their Antibacterial activity, Der Pharmacia Lettre, 8, 218-223.

Khadar, A., Behara, D.K., Kumar, M.K., 2016, Synthesis and Characterization of Controlled Size $\mathrm{TiO} 2$ Nanoparticles via Green Route using Aloe vera Extract, Int.J.Sci.Res., 5, 1913-1916.

Khalil, M.M.H., Ismail, E.H., El-Magdoub, F., 2012, Biosynthesis of $\mathrm{Au}$ nanoparticles using olive leaf extract: 1st Nano Updates, Arabian Journal of Chemistry, 5, 431-437. doi:10.1016/j.arabjc.2010.11.011

Krishnasamy, A., Sundaresan, M., Velan, P., 2015, Rapid phytosynthesis of nano-sized titanium using leaf extract of Azadirachta indica, International Journal of ChemTech Research, 8, 2047-2052.

Krithiga, N., Rajalakshmi, A., Jayachitra, A., 2015,. Green Synthesis of Silver Nanoparticles Using Leaf Extracts of Clitoria ternatea and Solanum nigrum and Study of Its Antibacterial ... Green Synthesis of Silver Nanoparticles Using Leaf Extracts of Clitoria ternatea and Solanum nigrum and Study of Its Antibacterial Effect against Common Nosocomial Pathogens, Journal of Nanoscience, Article ID: 928204. doi:10.1155/2015/928204

Kuang, Y., Wang, Q., Chena, Z., Megharaj, M., Kuang, R., Wang, Q., Zuliang Chena Mallavarapu Megharajb, c, R.N.N., 2013, Heterogeneous Fenton-like oxidation of monochlorobenzene using green synthesis of iron nanoparticles, Journal of Colloid and Interface Science, 410, 67-73.

Kumar Mittal, A., Chisti, Y., Banerjee, U.C., 2013, Synthesis of metallic nanoparticles using plant extracts, Biotechnology Advances, 31, 346356.

doi:10.1016/j.biotechadv.2013.01.003

Kuppusamy, P., Yusoff, M.M., Maniam, G.P., Govindan, N., 2016, Biosynthesis of metallic nanoparticles using plant derivatives and their new avenues in pharmacological applications - An updated report, Saudi Pharmaceutical Journal, 24, 473-484.

doi:10.1016/j.jsps.2014.11.013

Latha, N., Gowri, M., 2014, Bio Synthesis and Characterisation of $\mathrm{Fe} 3$ o 4 Nanoparticles Using Caricaya Papaya Leaves Extract, Int.J. Sci.Res., 3, 1551-1556.

Leonard, K., 2015, Green synthesis of mesoporous hematite ( $\alpha-\mathrm{Fe} 2 \mathrm{O} 3$ ) nanoparticles and their photocatalytic activity, Advanced Powder Technology 24, 160-167. doi:10.1016/j.apt.2012.04.005

M., S., SSundraraja, G., 2011, Green synthesis of titanium dioxide nanoparticles by nyctanthes arbortristis leaves extract, Chalcogenide Lett., 8, 447-451.

Manokari, M., Shekhawat, M.S., 2016a, Production of Zinc oxide nanoparticles using extracts of Passiflora edulis Sims . f . flavicarpa Deg ., J.Biological Paper, 47, 267278.

Manokari, M., Shekhawat, M.S., 2016b. Biogenesis of Zinc Oxide Nanoparticles using Couroupita guianensis Aubl . Extracts - A Green Approach, World Sci.News, 29, 135145. 
Manokari, M., Shekhawat, M.S., 2016c, Journal of Biological Papers Green synthesis of zinc oxide nanoparticles using plant extracts of Leucas aspera ( Willd .) L ., Int.J., Biol.Papers, 1, 22 27.

Marimuthu, S., Rahuman, A.A., Jayaseelan, C., Vishnu, A., Santhoshkumar, T., Velayutham, K., Bagavan, A., Kamaraj, C., Elango, G., Iyappan, M., Siva, C., Venkata, K., Rao, B., 2013, Acaricidal activity of synthesized titanium dioxide nanoparticles using Calotropis gigantea against Rhipicephalus microplus and Haemaphysalis bispinosa, Asian Pacific Journal of Tropical Medicine, 6, 682-688. doi:10.1016/S1995-7645(13)60118-2

Moldovan, B., David, L., Achim, M., Clichici, S., Filip, G.A., 2016, A green approach to phytomediated synthesis of silver nanoparticles using Sambucus nigra L. fruits extract and their antioxidant activity, Journal of Molecular Liquids, 221, 271-278.

Muralikrishna, T., Pattanayak, M., Nayak, P.L., 2014, Green Synthesis of Gold Nanoparticles Using (ALOE VERA) Aqueous Extract, World Journal of Nano Science \& Technology, 3, 4551.

doi:10.5829/idosi.wjnst.2014.3.2.111

Omidvari, A., Manteghi, F., Sohrabi, B., Afra, Y., 2014, A herbal extract for the synthesis of magnetite nanoparticles 2-5., Sci. Forum, doi:10.3390/ecsoc-18-b032

R, M.C.R., Rajalaxshmi, A., 2016, Green Synthesis , Characterization of $\mathrm{ZnO}$ nanoparticles and Ceion doped $\mathrm{ZnO}$ nanoparticles assisted Sesbania Grandiflora for photocatalytic application, Res.J. Mater.Sci., 4, 1-6.

Rajakumar, G., Rahuman, A.A., Jayaseelan, C., Santhoshkumar, T.,
Marimuthu, S., Kamaraj, C., Bagavan, A., Zahir, A.A., Kirthi, A.V., Elango, G., Arora, P., Karthikeyan, R., Manikandan, S., Jose, S., 2014, Solanum trilobatum extract-mediated synthesis of titaniumdioxide nanoparticles to control Pediculus humanus capitis, Hyalomma anatolicum anatolicum and Anopheles subpictus, Parasitol Res., 113, 469-479.

Rajakumar, G., Rahuman, A.A., Priyamvada, B., Khanna, V.G., Kumar, D.K., Sujin, P.J., 2012, Eclipta prostrata leaf aqueous extract mediated synthesis of titanium dioxide nanoparticles, Materials Letters, $\quad 68, \quad 115-117$. doi:10.1016/j.matlet.2011.10.038

Raut, S., Thorat, P. V, Thakre, R., 2015, Green Synthesis of Zinc Oxide ( $\mathrm{ZnO}$ ) Nanoparticles Using Ocimum Tenuiflorum Leaves, Int.J., Sci.Res., 4, 2013-2016.

Sadeghi, B., Mohammadzadeh, M., Babakhani, B., 2015, Green synthesis of gold nanoparticles using Stevia rebaudiana leaf extracts: Characterization and their stability, Journal of Photochemistry and Photobiology B: Biology, 148, 101106.

doi:10.1016/j.jphotobiol.2015.03.025

Saif, S., Tahir, A., Chen, Y., 2016, Green Synthesis of Iron Nanoparticles and Their Environmental Applications and Implications, Nanomaerials, 126. doi:10.3390/nano6110209

Sakthivel, R., Mallika, J., Kannusamy, R., Rajendran, R., 2016, Green Synthesis of Antibacterial Zinc Oxide Nanoparticles Using Biopolymer Azadirachta indica Gum, Oriental J.Chem., 32(2), 955-963.

Senthil, M., Ramesh, C., 2012, Biogenic synthesis of $\mathrm{Fe} 3 \mathrm{O} 4$ nanoparticles 
using Tridax procumbens leaf extract and its antibacterial activity on Pseudomonas aeruginosa, Digest Journal of Nanomaterials \& Biostructures, 7, 1655-1661.

Sharma, G., Sharma, A.R., Kurian, M., Bhavesh, R., Nam, J.S., Lee, S.S., 2014, Green synthesis of silver nanoparticle using Myristica fragrans (nutmeg) seed extract and its biological activity, Digest Journal of Nanomaterials and Biostructures, 9, 325-332.

Shenya, D.S., Philipa, D., Mathewb, J., 2013, Synthesis of platinum nanoparticles using dried Anacardium occidentale leaf and its catalytic and thermal applications, Spectrochimica Acta Part A: Molecular and Biomolecular Spectroscopy, 114, 267271.

Song, J.Y., Jang, H.-K., Kim, B.S., 2009, Biological synthesis of gold nanoparticles using Magnolia kobus and Diopyros kaki leaf extracts, Process Biochemistry, 44, 11331138.

doi:10.1016/j.procbio.2009.06.005

Sujitha, M. V., Kannan, S., 2013, Green synthesis of gold nanoparticles using Citrus fruits (Citrus limon, Citrus reticulata and Citrus sinensis) aqueous extract and its characterization,. Spectrochimica Acta Part A: Molecular and Biomolecular Spectroscopy, 102, 15-23. doi:10.1016/j.saa.2012.09.042

Umoren, S.A., Obot, I.B., Gasem, Z.M., 2014, Green Synthesis and Characterization of Silver Nanoparticles Using Red Apple ( Malus domestica) Fruit Extract at Room Temperature, J. Mater.
Environ. Sci., 5, 907-914.

Vankar, P.S., Shukla, D., 2012, Biosynthesis of silver nanoparticles using lemon leaves extract and its application for antimicrobial finish on fabric, Applied Nanoscience, 2, 163168. doi:10.1007/s13204-011-0051-y

Vijayashree, I.S., Yallappa, S., Niranjana, P., Manjanna, J., 2014, Microwave assisted synthesis of stable biofunctionalized silver nanoparticles using apple fruit ( Malus domestica ) extract, Adv. Matter Lett., 4, 598-603. doi:10.5185/amlett.2014.5680

VP, M., Muthukumar K., 2016, Ultrasound assisted green synthesis of silver nanoparticles using weed plant, Bioprocess Biosyst Eng., 39, 401411.

Yedurkar, S., Maurya, C., Mahanwar, P., 2016, Biosynthesis of Zinc Oxide Nanoparticles Using Ixora Coccinea Leaf Extract - A Green Approach, Open J.Synth. Res.Appl., 1-14. doi:10.4236/ojsta.2016.51001

Zahir, A.A., Chauhan, I.S., Bagavan, A., Kamaraj, C., Elango, G., Shankar, J., Arjaria, N., 2014, Synthesis of Nanoparticles Using Euphorbia prostrata Extract Reveals a Shift from Apoptosis to G0 / G1 Arrest in Leishmania donovani, J. Nanomedicine and Nanoscience, 5, 213-210. doi:10.4172/21577439.1000213

Zia, M., 2016, Antioxidant, cytotoxic and antimicrobial activities of green synthesized silver nanoparticles from crude extract of Bergenia ciliata, Future Journal of Pharmaceutical sciences, $\quad \mathbf{2 ( 1 ) ,}$ 31-36. doi:10.1016/j.fjps.2016.03.001. 